\title{
Potential of medicinal plants to treat dengue
}

\author{
Dulanjalee Neelawala, Sanjaya Rajapakse and Wikum Widuranga Kumbukgolla \\ Department of Biochemistry, Faculty of Medicine and Allied Sciences, Rajarata University of Sri Lanka, \\ Anuradhapura 50000, Sri Lanka. \\ Corresponding author: Dulanjalee Neelawala, e-mail: dulanjaleen1@gmail.com \\ Co-authors: SR: sanjayakiri@gmail.com, WWK: kumbukgolla@yahoo.com \\ Received: 13-03-2019, Accepted: 05-08-2019, Published online: 08-10-2019
}

doi: 10.14202/IJOH.2019.86-91 How to cite this article: Neelawala D, Rajapakse S, Kumbukgolla WW. Potential of medicinal plants to treat dengue. Int J One Health 2019;5:86-91.

\begin{abstract}
Dengue is a major public health challenge worldwide, particularly in tropical areas. Nearly 390 million infections and 22,000 deaths occur every year. At present, there are no specific therapeutics available to treat dengue; however, possible treatment procedures are explained in the traditional medical systems (TMSs), such as Sri Lankan TMS, Indian Ayurvedic, Unani, and Siddha TMS. In these TMSs, medicinal plants have been used in several ways against dengue, such as virocides, larvicides, and mosquito repellents. Therefore, medicinal plants inherit biologically active compounds/lead compounds that are yet to be identified chemically and physiologically. Herein, we discuss the possible applications of crude plant extracts and isolated phytochemicals from medicinal plants such as quercetin, sulfated galactomannans, flavonoids, and glabranine in controlling dengue. Moreover, medicinal plant-based therapeutics can be safer, cost-effective, and non-toxic. Therefore, this paper reviews the medicinal plants that are used in TMSs to manage dengue, the phytochemicals they contain, and mode of action of these phytochemicals such as virocides, larvicides, and mosquito repellents.
\end{abstract}

Keywords: dengue, in silico, larvicides, phytochemicals, virocides.

\section{Introduction}

Dengue is a life-threatening arboviral disease, with nearly 390 million cases annually and high mortality worldwide [1]. According to the World Health Organization records, around 22,000 deaths occur due to dengue annually, especially in pediatric patients [2]. The first evidence of dengue was in a Chinese medical encyclopedia of 265-420 AD, in which the dengue has been denoted as "poison water combined with flying insects." Subsequently, the most famous dengue fever outbreaks occurred in 1635 and 1699 in the Caribbean region. In South Asia, the first dengue epidemic in Sri Lanka occurred in the period from 1965 to 1968, causing 51 dengue hemorrhagic fever cases and 15 deaths, while the largest epidemic occurred in 2017, causing 186,101 cases [3]. In India, until 2015, Delhi has experienced eight dengue outbreaks since 1967, with the last epidemic reported in 2006 [4].

The usage of medicinal plants in treating infections started in the prehistoric period. The ancient Unani manuscripts, Egyptian papyrus, and Chinese writings provide written evidence of this practice. Furthermore, Unani Hakims, Indian Vaiydas, and Mediterranean cultures have been using medicinal plants for 4000 years. The traditional medical systems (TMSs) in Asia utilize medicinal plants to manage dengue. Medicinal plants contain lead compounds/

Copyright: Neelawala, et al. This article is an open access article distributed under the terms of the Creative Commons Attribution 4.0 International License (http://creativecommons.org/licenses/ by/4.0/), which permits unrestricted use, distribution, and reproduction in any medium, provided you give appropriate credit to the original author(s) and the source, provide a link to the Creative Commons license, and indicate if changes were made. The Creative Commons Public Domain Dedication waiver (http:// creativecommons.org/ publicdomain/zero/1.0/) applies to the data made available in this article, unless otherwise stated. phytochemicals that have the potential to act as virocides and larvicides against the dengue virus and mosquito repellents against the dengue vector mosquitoes. Moreover, with advancements in modern technology, the usage of medicinal plants is increasing as a constituent of in silico drug development and anti-dengue vaccine production.

The medicinal plants used in different TMSs as virocides, larvicides, and mosquito repellents, mode of action of phytochemicals isolated from these medicinal plants, and use of plant-based lead compounds in in silico drug development and anti-dengue vaccine production are discussed in this review.

\section{Medicinal Plants used in TMSs to Treat Dengue}

The TMSs that use medicinal plants for anti-dengue treatment are especially popular in Asian countries such as India, Malaysia, China, Thailand, and Sri Lanka. The usage of medicinal plant preparations to treat dengue may have several advantages over commercial anti-dengue, such as safety, cost-effectiveness, and non-toxicity [5]. Anti-dengue properties of some medicinal plants used in different TMs are described in Table-1 [6-22].

\section{Virocidal and Immunomodulatory Activities of Medicinal Plants}

The medicinal plant extracts contain different phytochemicals that can be used to treat dengue. These extracts or molecules can act as virocides and immunomodulators.

\section{Bioactive phytochemicals in different medicinal plants}

Medicinal plant resources provide various phytochemicals with different anti-dengue virocidal 
Table-1: Anti-dengue properties of some medicinal plants used in different TMSs.

\begin{tabular}{|c|c|c|c|c|}
\hline TMS & Medicinal plant & Type of extract & Anti-dengue activity & References \\
\hline \multirow[t]{3}{*}{ Sri Lankan TMS } & Carica papaya & Aqueous extract & $\begin{array}{l}\text { Optimization of clotting time and } \\
\text { elevation of the platelet count }\end{array}$ & [6] \\
\hline & Euphorbia hirta & Petroleum ether extract & $\begin{array}{l}\text { Antipyretic activity, elevation of } \\
\text { the platelet count, and prevention } \\
\text { of bleeding }\end{array}$ & [7] \\
\hline & Ocimum sanctum & Methanol extract & Larvicidal activity & [8] \\
\hline \multirow[t]{4}{*}{ Indian Ayurvedic } & Tinospora cordifolia & Leaf extract & $\begin{array}{l}\text { Antipyretic and anti-inflammatory } \\
\text { properties }\end{array}$ & [9] \\
\hline & Ocimum tenuiflorum & Leaf extract & Anti-inflammatory properties & {$[10]$} \\
\hline & Zingiber officinalis & Root extract & Larvicidal activity & {$[11]$} \\
\hline & Carica papaya & Aqueous extract & $\begin{array}{l}\text { Optimization of clotting time and } \\
\text { elevation of the platelet count }\end{array}$ & {$[6]$} \\
\hline \multirow[t]{7}{*}{ Siddha medicine } & Andrographis paniculata & Methanol extracts & $\begin{array}{l}\text { Virocidal activity against the } \\
\text { dengue virus DENV-1 }\end{array}$ & {$[12]$} \\
\hline & Vetiveria zizanioides & $\begin{array}{l}\text { Ethyl 4-(4-methylphenyl) } \\
\text {-4-pentenoate extract }\end{array}$ & $\begin{array}{l}\text { Inhibition of dengue NS2B-NS3 } \\
\text { protease and prevention of the } \\
\text { viral assembly }\end{array}$ & [13] \\
\hline & Plectranthus vettiveroides & Root extract & Antipyretic properties & {$[14]$} \\
\hline & Santalum album & Essential oils & Anti-dengue virocidal activity & {$[15]$} \\
\hline & Cyperus rotundus & Essential oils & Ovicidal and larvicidal activity & {$[16]$} \\
\hline & Zingiber officinale & Root extract & Larvicidal activity & {$[11]$} \\
\hline & Piper nigrum & Fruit ethanolic extract & Larvicidal activity & {$[17]$} \\
\hline \multirow[t]{2}{*}{ Unani medicine } & Carica papaya & Aqueous extract & $\begin{array}{l}\text { Optimization of clotting time and } \\
\text { elevation of the platelet count }\end{array}$ & {$[6]$} \\
\hline & Euphorbia hirta & Petroleum ether extract & $\begin{array}{l}\text { Antipyretic activity, elevation of } \\
\text { the platelet count, and prevention } \\
\text { of bleeding }\end{array}$ & [7] \\
\hline Not specified & Alternanthera philoxeroides & Petroleum ether extract & Anti-dengue virocidal activity & {$[18]$} \\
\hline Not specified & Hippophae rhamnoides & Ethanol and water extracts & $\begin{array}{l}\text { Virocidal activity against the } \\
\text { dengue virus DENV-2 }\end{array}$ & [19] \\
\hline Not specified & $\begin{array}{l}\text { Cladogynos orientalis, } \\
\text { Rhizophora apiculata, } \\
\text { Flagellaria indica, } \\
\text { Houttuynia cordata }\end{array}$ & $\begin{array}{l}\text { Dichloromethane and } \\
\text { ethanol extracts }\end{array}$ & $\begin{array}{l}\text { Virocidal activity against the } \\
\text { dengue virus DENV-2 }\end{array}$ & {$[20]$} \\
\hline Not specified & Alternanthera philoxeroides & Petroleum ether extract & Anti-dengue virocidal activity & {$[18]$} \\
\hline Not specified & Hypericum mysorense & $\begin{array}{l}\text { Extracts from different } \\
\text { plant parts }\end{array}$ & Anti-dengue virocidal activity & [21] \\
\hline Not specified & Usnea complanta & $\begin{array}{l}\text { Extracts from different } \\
\text { plant parts }\end{array}$ & Anti-dengue virocidal activity & {$[21]$} \\
\hline Not specified & Hypericum hookerianum & $\begin{array}{l}\text { Extracts from different } \\
\text { plant parts }\end{array}$ & Anti-dengue virocidal activity & [21] \\
\hline Not specified & Quercus lusitanica & Methanolic seed extract & $\begin{array}{l}\text { Virocidal activity against the } \\
\text { dengue virus DENV-2 }\end{array}$ & [22] \\
\hline
\end{tabular}

TMSs $=$ Traditional medical systems

mechanisms such as inhibition of virus replication in the host, prevention of virus adsorption in the host cells, and prevention of the entry of the virus in the host cells. Different phytochemicals contain different molecular compounds such as alkaloids and carbohydrates. Alkaloid phytochemicals can inhibit replication of the dengue virus [23], while carbohydrate phytochemicals including glycosphingolipids, sulfated glycosaminoglycans, and lectins prevent cell entry of the virus [24].

In a study in India, in 2016, Mishra found three main phytochemicals that possess anti-dengue properties: Flavanones, dicoumarols, and terpins [25]. The flavanones belong to the class of flavonoids. Frabasile et al. revealed that citrus flavonoid naringenin can prevent infection of all four dengue virus serotypes in Huh7.5 cells [26]. Table-2 summarizes the different phytochemicals in medicinal plants and their modes of action [5,27-34].

\section{Mosquito Repellent and Larvicidal Activity of Medicinal Plants}

Aedes aegypti is the primary vector mosquito of the dengue virus, while Aedes albopictus acts as a secondary vector in cooler climates [35]. Some medicinal plants contain aromatic essential oils and compounds that can act as mosquito repellents and larvicides. These essential oils and compounds are usually produced by plants for protection against microorganisms and other harmful organisms. Therefore, studies have been performed to validate the use of these compounds as dengue vector mosquito repellents and larvicides.

In Argentina, medicinal plants are widely used as mosquito repellents and larvicides. In a study in Argentina, Gillij et al. assayed the mosquito repellent activity of several medicinal plants and found that of 12 aromatic plants, three (Baccharis spartioides, Rosmarinus officinalis, and Aloysia citrodora) were 
Table-2: Mode of action of phytochemicals extracted from medicinal plants.

\begin{tabular}{|c|c|c|c|}
\hline Medicinal plant & Phytochemicals & Mode of action & References \\
\hline Psidium guava & Quercetin & $\begin{array}{l}\text { Elevation of the platelet count and prevention of } \\
\text { bleeding and mRNA formation of the virus DENV- } 2\end{array}$ & {$[5]$} \\
\hline $\begin{array}{l}\text { Mimosa scabrella and } \\
\text { Leucaena leucocephala }\end{array}$ & Sulfated galactomannans & Anti-dengue virocidal activity & [27] \\
\hline $\begin{array}{l}\text { Tephrosia madrensis, } \\
\text { Tephrosia viridiflora, and } \\
\text { Tephrosia crassifolia }\end{array}$ & $\begin{array}{l}\text { Flavonoids, glabranine, and } \\
\text { 7-O-methyl-glabranine }\end{array}$ & Anti-dengue virocidal activity & {$[28]$} \\
\hline Ocimum sanctum & Eugenol and ursolic acid & Anti-dengue viral and antipyretic activities & [29] \\
\hline Azadirachta indica & Azadirachtin & Inhibition of the replication of DENV-2 & [30] \\
\hline $\begin{array}{l}\text { Red seaweed } \\
\text { Gymnogongrus torulosus }\end{array}$ & D-galactose & $\begin{array}{l}\text { Optimum dengue inhibitory activity in the phase } \\
\text { of virus adsorption in the host cells by interfering } \\
\text { between the virus particles and cell receptors }\end{array}$ & [31] \\
\hline Meristiella gelidium & Carrageenan & Anti-dengue virocidal activity & [32] \\
\hline $\begin{array}{l}\text { Marine algae } \\
\text { Cladosiphon okamuranus }\end{array}$ & $\begin{array}{l}\text { Fucoidan, a sulfated } \\
\text { polysaccharide }\end{array}$ & Virocidal activity against the virus DENV-2 & [33] \\
\hline Cyclohexenyl chalcone & $\begin{array}{l}\text { 4-hydroxypanduratin } \mathrm{A} \text { and } \\
\text { panduratin }\end{array}$ & $\begin{array}{l}\text { Higher inhibitory activities against DENV-2 and NS3 } \\
\text { protease }\end{array}$ & [34] \\
\hline
\end{tabular}

effective against Aedes [36]. Several other studies revealed the ability of medicinal plants to act as mosquito repellents and larvicides. Ocimum sanctum, commonly known as the holy basil, contains phytochemicals such as eugenol, caryophyllene, alpha-farnesene, and farnesyl acetone that are effective against dengue vector mosquitoes [37]. Eugenol belongs to the class of allylbenzene and contains an allyl chain substituted with guaiacol, while caryophyllene is a natural bicyclic sesquiterpene that is a constituent of many essential oils. Govindarajan et al. showed that eugenol and caryophyllene have acute toxicity against the third instar larvae of $A$. albopictus [38]. Eclipta prostrata and Annona squamosa have better larvicidal activities [39].

The leaf and stem/bark extracts of Jatropha curcas, Citrus grandis, and Tinospora rumphii are effective against larvicidal activities. Alkaloids, flavonoids, and steroids in $J$. curcas and alkaloids, saponins, tannins, flavonoids, and steroids in $C$. grandis and $T$. rumphii are toxic to the third instar larvae of A. aegypti [40].

\section{Medicinal Plants as a Constituent of In Silico Drug Development}

There are many sources of information on medicinal plants. Therefore, it is difficult for plant-based researchers to identify the potential medicinal plants to develop novel anti-dengue drugs. However, multitarget drug designing and bioinformatic approaches, such as computational methods (in silico methods), are becoming popular $[41,42]$.

Some in silico methods used in drug development processes are molecular docking, structure-activity relationship (SAR), quantitative SAR (QSAR) models, and pharmacophore techniques. In these methods, the drug target molecules are identified by employing bioinformatics tools. Phytochemicals are matched with their viral targets to find interactions between the drug and the disease-producing agents and reveal the treatment. The atomic-level structural information can be obtained using the docking, SAR, and QSAR methods.

In the molecular docking method, phytochemicals are matched with the protein targets of the dengue virus [43]. The most effective targets of the dengue virus are NS5 RNA-dependent RNA polymerase, NS5 methyltransferase, NS3 protease, NS3 helicase, and envelope glycoprotein [44]. NS4B in DENV-1, DENV2, and DENV-4 has binding sites for phytochemicals such as epicatechin, catechin, eupatoretin, cianidanol, laurifolin, glabranin, and DL-catechinare [45]. NS2b/ NS3 protease of DENV-1, DENV-2, and DENV-3 is good binding sites for antiviral ligands [46].

Suganya and Mahendran, in 2016, performed a study to design in silico actives against the dengue virus using new plant actives. In that study, 75 medicinal plant actives were subjected to QSAR and molecular docking procedures. Eleven inhibitory compounds against NS5 and eight inhibitory compounds against NS3 were identified using the QSAR method, while 13 inhibitory compounds against NS5 and three inhibitory compounds against NS3 were identified using the molecular docking method [47].

The multitarget drug designing shows better results with effective drug actives that can act simultaneously with the targets [48]. The least binding energy in the molecular docking analysis shows stronger docking between the ligands and viral targets [47]. NS3 and NS5 act as protective, non-structural, multifunctional proteins, and creating various enzymatic activities, which allow the development of drugs acting on all four serotypes of DENV [49]. Qaddir et al. [50] found novel DENV inhibitors such as derrisin, mundulinol, and isopomiferin from the medicinal plant Silybum marianum and narlumicine and oxysanguinarine from Fumaria indica using the absorption, distribution, metabolism, excretion, and toxicity analysis and docking method. Sonneratia alba can synthesize silver nanoparticles, which can be used to produce environment-friendly nanoformulations, which have shown better activity against DENV and dengue vectors [51]. 
Alkaloid, rohitukine, has exhibited better interaction against NS5 dengue antigen [52].

\section{Usage of Medicinal Plants for Anti-Dengue Vaccine Production}

The development of anti-dengue vaccine started with clinical trials in 1970 [53]. However, there are no licensed anti-dengue vaccines available commercially [54]. An effective and safe anti-dengue vaccine with long-term action is required due to the rapid spread of dengue in the tropics [55]. However, there are several impediments that make it hard to develop a vaccine that is effective against all four serotypes. Some of them are the vast epidemiological distribution of the four DENV serotypes, complex immunoprotective and/or immunopathogenic responses following natural infection or vaccination, and a lack of validated animal models [56]. The complex immunopathogenic responses of dengue may have been caused by antibody-dependent enhancement [57-59], and cytokine storm resulted from the activation of cell-mediated immunity [60], complement activation [61], and development of autoimmunity. Furthermore, manufactured vaccines occasionally show enhanced pathogenicity instead of protection [62].

Medicinal plants would provide a better option to overcome these impediments because plant-derived vaccine production is cheaper, efficient and requires easy techniques compared to those used in animal-based vaccine production. [63]. Another advantage of plant-based vaccine production is that the processes involved in vaccine production, such as fermentation, purification, cold storage, sterile delivery, and transportation, are inexpensive [64].

Dengue antigen protein-encoding genes can be incorporated in the genetic material of the plant tissues. The particle bombardment gene delivery method and chloroplast transformation through biolistic particle delivery system are popular gene delivery techniques for good quality plant-derived vaccine production. Furthermore, transformation through genetically modified plant virus and Agrobacterium-mediated gene transferring techniques are currently used to produce vaccines. Recent advances in plant-derived vaccine production are biolistics, electroporation, agroinfiltration, sonication, and polyethylene glycol treatment [65].

\section{Conclusion}

Many medicinal plant extracts and ingredient compounds have shown promising inhibitory activity against dengue based on the aforementioned data. The structure-activity relationship of these active compounds can be determined with the in silico approach. Moreover, the in silico modeling of drugs can be conducted using the lead templates of active plant-based compounds. Development of a vaccine against dengue is a challenge, and several previous approaches have failed. However, plant-based vaccines could be less toxic and more cost-effective. Therefore, novel plantbased drug development initiatives are important in controlling dengue.

\section{Authors' Contributions}

WWK stipulated the hypothesis. DN and SR conducted a literature survey. The manuscript was written by WWK and DN. All authors read and approved the final manuscript.

\section{Acknowledgment}

We would like to thank the Department of Biochemistry, Faculty of Medicine and Allied Sciences, Rajarata University of Sri Lanka, for providing a pleasant environment to work on this review.

\section{Competing Interests}

The authors declare that they have no competing interests.

\section{Publisher's Note}

Veterinary World (Publisher of International Journal of One Health) remains neutral with regard to jurisdictional claims in published institutional affiliation.

\section{References}

1. WHO. Dengue Control-Epidemiology. WHO; 2017. Available from: https://www.who.int/denguecontrol/epidemiology/en. [Last accessed on 2019 Mar 10].

2. WHO. Neglected Tropical Diseases, Dengue, Dengue Fact Sheet. WHO; 2019. Available from: http://www.searo.who. int/entity/vector borne tropical diseases/data/data factsheet/en. [Last accessed on 2019 Mar 10].

3. Epidemiology Unit, Ministry of Health, Sri Lanka, Trends; 2019. Available from: http://www.epid.gov.lk/web/index. php?option $=$ com_casesanddeaths\&Itemid $=448 \&$ lang $=$ en . [Last accessed on 2019 Mar 4].

4. Ahmed NH, Broor S. Dengue fever outbreak in Delhi, North India: A clinico-epidemiological study. Indian J Community Med 2015;40:135-8.

5. Abd Kadir SL, Yaakob H, Mohamed Zulkifli R. Potential anti-dengue medicinal plants: A review. J Nat Med 2013;67:677-89.

6. Ahmad N, Fazal H, Ayaz M, Abbasi BH, Mohammad I, Fazal L, et al. Dengue fever treatment with Carica papaya leaves extracts. Asian Pac J Trop Biomed 2011;1:330-3.

7. Rahuman AA, Gopalakrishnan G, Venkatesan P, Geetha K. Larvicidal activity of some Euphorbiaceae plant extracts against Aedes aegypti and Culex quinquefasciatus (Diptera: Culicidae). Parasitol Res 2008;102:867-73.

8. Anees AM. Larvicidal activity of ocimum sanctum linn. (Labiatae) against Aedes aegypti (L.) and Culex quinquefasciatus (Say). Parasitol Res 2008;103:1451-3.

9. Saxena SK. Complementary and alternative medicine in alliance with conventional medicine for dengue therapeutics and prevention. Future Virol 2017;12:399-402.

10. Kashif M, Ullah S. Chemical composition and minerals analysis of Hippophae rhamnoides, Azadirachta indica, Punica granatu and Ocimum sanctum leaves. World J Dairy Food Sci 2013;8:67-73.

11. Rabha B, Gopalakrishnan R, Baruah I, Singh L. Larvicidal activity of some essential oil hydrolates against dengue and filariasis vectors. Indian J Med Res 2012;1:14-6.

12. Tang LI, Ling AP, Voon KG. Screening of anti-dengue activity in methanolic extracts of medicinal plants background methods plant materials and extraction. BMC Complement 
Altern Med 2014; $1: 3$.

13. Sudha PL, Anand R. Ethyl 4(4-methylphenyl) -4-pentenoate from Vetiveria zizanioides inhibits dengue NS2B-NS3 protease and prevents viral assembly : A computational molecular dynamics and docking study. Cell Biochem Biophys 2016; 74: 337-351.

14. Nisheeda BA, Safeer PM, Sreekumar S, Biju CK, Seeja G, Manivannan C. A review on Plectranthus vettiveroides: An endemic to South Indian high value aromatic medicinal plant. IOSR J Pharm Biol Sci 2016;11:1-11.

15. Reichling J, Schnitzler P, Suschke U, Saller R. Essential oils of aromatic plants with antibacterial, antifungal, antiviral, and cytotoxic properties an overview. Forsch Komplementmed 2009;16:79-90.

16. Kempraj V, Bhat SK. Vahl and Cyperus rotundus Linn. Essential oils against Aedes albopictus (Skuse). Nat Prod Res 2008;7:416-9.

17. Grzybowski A, Tiboni M, Silva MA, Chitolina RF, Passos M, Fontana JD, et al. Synergistic larvicidal effect and morphological alterations induced by ethanolic extracts of Annona muricata and Piper nigrum against the dengue fever vector Aedes aegypti. Pest Manag Sci 2013;69:589-601.

18. SarangiMK,PhadiS.Dengueanditsphytotherapy :Areview.Int J Pharm Phytopharmacol 2014;4:37-46.

19. Jain M, Ganju L, Katiyal A, Padwad Y, Mishra KP, Chanda S, et al. Effect of Hippophae rhamnoides leaf extract against dengue virus infection in human blood-derived macrophages. Phytomedicine 2008;15:793-9.

20. Klawikkan N. Effect of Thai medicinal plant extracts against dengue virus in vitro. Int J Med Aromat Plants 2012;2:1-21.

21. Vijayan P, Raghu C, Ashok G, Dhanaraj SA, Suresh B. Antiviral activity of medicinal plants of Nilgiris. Indian J Med Res 2004;120:24-9.

22. Muliawan SY, Kit LS, Devi S, Hashim O, Yusof R. Inhibitory potential of Quercus lusitanica extract on dengue virus Type 2 replication. Southeast Asian J Trop Med Public Health 2006;37 Suppl 3:132-5.

23. Ul Qamar MT, Mumtaz A, Ashfaq UA, Adeel MM, Fatima T. Potential of plant alkaloids as dengue ns 3 protease inhibitors: Molecular docking and simulation approach. Bangladesh J Pharmacol 2014;9:262-7.

24. Hidari KI, Abe T, Suzuki T. Carbohydrate-related inhibitors of dengue virus entry. Viruses 2013;5:605-18.

25. Mishra P. Evaluation of Phytochemical Compounds from Carica papaya as Potential Drugs against Dengue virus: An In silico Approach, Thesis 2016; Orissa University of Agriculture and Technology, Bhubaneswar.

26. Frabasile S, Koishi AC, Kuczera D, Silveira GF, Verri WA Jr., Duarte Dos Santos CN, et al. The citrus flavanone naringenin impairs dengue virus replication in human cells. Sci Rep 2017;7:41864.

27. Ono L, Wollinger W, Rocco IM, Coimbra TL, Gorin PA, Sierakowski MR, et al. In vitro and in vivo antiviral properties of sulfated galactomannans against yellow fever virus (BeH111 strain) and dengue 1 virus (Hawaii strain). Antiviral Res 2003;60:201-8.

28. Sánchez I, Gómez-Garibay F, Taboada J, Ruiz BH. Antiviral effect of flavonoids on the dengue virus. Phytother Res 2000;14:89-92.

29. Anandjiwala S, Kalola J, Rajani M. Quantification of eugenol, luteolin, ursolic acid, and oleanolic acid in black (Krishna tulasi) and green (Sri tulasi) varieties of Ocimum sanctum linn. Using high-performance thin-layer chromatography. J AOAC Int 2006;89:1467-74.

30. Parida MM, Upadhyay C, Pandya G, Jana AM. Inhibitory potential of neem (Azadirachta indica juss) leaves on dengue virus Type-2 replication. J Ethnopharmacol 2002;79:273-8.

31. Pujol CA, Estevez JM, Carlucci MJ, Ciancia M, Cerezo AS, Damonte EB, et al. Novel DL-galactan hybrids from the red seaweed Gymnogongrus torulosus are potent inhibitors of herpes simplex virus and dengue virus. Antivir Chem Chemother 2002;13:83-9.
32. F-tischer PC, Talarico LB, Noseda MD, Guimarães SM. Chemical structure and antiviral activity of carrageenans from Meristiella gelidium against herpes simplex and dengue virus. Carbohydr Polym 2006;63:459-65.

33. Hidari KI, Takahashi N, Arihara M, Nagaoka M. Biochemical and biophysical research communications structure and anti-dengue virus activity of sulfated polysaccharide from a marine alga. Biochem Biophys Res Commun 2008;376:91-5.

34. Kiat TS, Pippen R, Yusof R, Ibrahim H, Khalid N, Rahman NA, et al. Inhibitory activity of cyclohexenyl chalcone derivatives and flavonoids of fingerroot, Boesenbergia rotunda (L.), towards dengue-2 virus NS3 protease. Bioorg Med Chem Lett 2006;16:3337-40.

35. Brady OJ, Gething PW, Bhatt S, Messina JP, Brownstein JS, Hoen AG, et al. Refining the global spatial limits of dengue virus transmission by evidence-based consensus. PLoS Negl Trop Dis 2012;6:e1760.

36. Gillij YG, Gleiser RM, Zygadlo JA. Mosquito repellent activity of essential oils of aromatic plants growing in Argentina. Bioresour Technol 2008;99:2507-15.

37. Shazad M, Gupta KK, Kayesth S, Kumar S. Sublethal effects of ethanol extract of Ocimum sanctum on laboratory-bred population of dengue mosquito Aedes aegypti L. (Diptera: Culicidae). Vector Biol J 2018;3:1-7.

38. Govindarajan M, Rajeswary M, Hoti SL, Benelli G. Larvicidal potential of carvacrol and terpinen-4-ol from the essential oil of Origanum vulgare (Lamiaceae) against Anopheles stephensi, Anopheles subpictus, Culex quinquefasciatus and Culex tritaeniorhynchus (Diptera: Culicidae). Res Vet Sci 2016;104:77-82.

39. Zameer S, Khader A, Syed S, Ahmed Z, Sathyan J, Mahboob MR, et al. A comparative study on larvicidal potential of selected medicinal plants over green synthesized silver nanoparticles. Egypt J Basic Appl Sci 2018;5:54-62.

40. Gutierrez PM, Antepuesto AN, Eugenio BA, Santos MF. Larvicidal activity of selected plant extracts against the dengue vector Aedes aegypti mosquito. Int Res J Biol Sci 2014;3:23-32.

41. Sharma V, Sarkar IN. Bioinformatics opportunities for identification and study of medicinal plants. Brief Bioinform 2013;14:238-50.

42. Negi B, Kumar D, Kumbukgolla W, Jayaweera S, Ponnan P, Singh R, et al. Anti-methicillin resistant Staphylococcus aureus activity, synergism with oxacillin and molecular docking studies of metronidazole-triazole hybrids. Eur J Med Chem 2016;115:426-37.

43. Powers CN, Setzer WN. An in-silico investigation of phytochemicals as antiviral agents against dengue fever. Comb Chem High Throughput Screen 2016;19:516-36.

44. Sampath A, Padmanabhan R. Molecular targets for flavivirus drug discovery. Antiviral Res 2009;81:6-15.

45. Paul A, Vibhuti A, Raj S. Molecular docking NS4B of DENV 1-4 with known bioactive phytochemicals. Bioinformation 2016;12:140-8

46. Verma R, Jatav VK, Sharma S. Identification of inhibitors of dengue virus (DENV1, DENV2 and DENV3) NS2B/NS3 serine protease: A molecular docking and simulation approach. Asian J Pharm Clin Res 2015;8:4-9.

47. Suganya J, Mahendran R. In silico QSAR and molecular docking studies of selected medicinal plant compounds against NS5 and NS3 protein of dengue virus: A comparative approach. Int J Pharm Bio Sci 2016;7:1135-44.

48. Abdolmaleki A, Ghasemi JB, Ghasemi F. Computer-aided drug design for multi-target drug design: SAR/QSAR, molecular docking and pharmacophore methods. Curr Drug Targets 2017; 18:556-75.

49. De Oliveira AS, Da Silva ML, Oliveira AF, Da Silva CC, Teixeira RR, De Paula SO. NS3 and NS5 proteins: Important targets for anti-dengue drug design. J Braz Chem Soc 2014;25:1759-69.

50. Qaddir I, Rasool N, Hussain W, Mahmood S. Computer-aided 
analysis of phytochemicals as potential dengue virus inhibitors based on molecular docking, ADMET and DFT studies. J Vector Borne Dis 2017;54:255-62.

51. Murugan K, Dinesh D, Paulpandi M, Subramaniam J, Rakesh R, Amuthavalli P, et al. Sonneratia alba-synthesized silver nanoparticles magnify guppy fish predation against Aedes aegypti young instars and down-regulate the expression of envelope (E) gene in dengue virus (Serotype DEN-2). J Clust Sci 2017;28:437-61.

52. Niranjan K, Kumar M, Bhatnagar S. Identification of novel inhibitor against dengue NS5. Int J Adv Pharm 2017;6:114-8.

53. Thisyakorn U, Thisyakorn C. Dengue Vaccines. Vaccines 2015;46:138-45.

54. Bhatt S, Gething PW, Brady OJ, Messina JP, Farlow AW, Moyes CL, et al. The global distribution and burden of dengue. Nature 2013;496:504-7.

55. Webster DP, Farrar J, Rowland-Jones S. Progress towards a dengue vaccine. Lancet Infect Dis 2009;9:678-87.

56. McArthur MA, Sztein MB, Edelman R. Dengue vaccines: Recent developments, ongoing challenges and current candidates. Expert Rev Vaccines 2013;12:933-53.

57. Wahala WM, Silva AM. The human antibody response to dengue virus infection. Viruses 2011;3:2374-95.

58. Ornelas AM, Aguiar RS, Vincenti-Gonzalez MF, Cadar D, Schmidt-Chanasit J, Barzon L, et al. Dengue virus IgM serotyping by ELISA with recombinant mutant envelope proteins. Emerg Infect Dis 2018;25:1111-5.

59. Rockstroh A, Moges B, Barzon L, Sinigaglia A, Palù G, Kumbukgolla W, et al. Specific detection of dengue and Zika virus antibodies using envelope proteins with mutations in the conserved fusion loop. Emerg Microbes Infect 2017;6:e99.

60. Pang T, Cardosa MJ, Guzman MG. Of cascades and perfect storms: The immunopathogenesis of dengue hemorrhagic fever-dengue shock syndrome (DHF/DSS). Immunol Cell Biol 2007;85:43-5.

61. Avirutnan P, Punyadee N, Noisakran S, Komoltri C, Thiemmeca S, Auethavornanan K, et al. Vascular leakage in severe dengue virus infections: A potential role for the nonstructural viral protein NS1 and complement. J Infect Dis 2006;193:1078-88.

62. Yauch LE, Shresta S. Dengue virus vaccine development. Adv Virus Res 2014;88:315-72.

63. Malabadi RB, Meti NT, Mulgund GS, Nataraja K, Kumar SV. Recent advances in plant derived vaccine antigens against human infectious diseases. Res Pharm 2012;2:8-19.

64. Daniell H, Singh ND, Mason H, Streatfield SJ. Plant-made vaccine antigens and biopharmaceuticals. Trends Plant Sci 2009; 14:669-79.

65. Laere E, Pick A, Ling K, Wong YP, Koh RY, Azmi M, et al. Plant-based vaccines: Production and challenges. J Bot 2016;2016:1-11. 